R. M. Harveson

University of Nebraska, Panhandle

Research and Extension Center, Scottsbluff

C. E. Windels

University of Minnesota,

Northwest Research and Outreach Center, Crookston

J. A. Smith

University of Nebraska, Panhandle

Research and Extension Center, Scottsbluff

J. R. Brantner

University of Minnesota,

Northwest Research and Outreach Center, Crookston
A. W. Cattanach

American Crystal Sugar Company,

Moorhead, MN

J. F. Giles

North Dakota State University, Fargo

L. Hubbell

Monitor Sugar Company, Bay City, MI

N. R. Cattanach

North Dakota State University, Fargo

\title{
Fungicide Registration and a Small Niche Market: A Case History of Hymexazol Seed Treatment and the U.S. Sugar Beet Industry
}

The United States ranks among the top four sugar producers worldwide, and sugar beet (Beta vulgaris L.) plays a major role in the sweetener industry. Sugar beet was planted on approximately 553,100 ha (1.37 million acres) in 2006 (33). The greatest volume of production occurs in the Red River Valley (RRV) of Minnesota and North Dakota and in southern Minnesota. In 2005, this region planted 302,000 ha (746,000 acres) of sugar beet, which accounted for over half of the hectares sown $(58 \%)$ and metric tons of roots produced $(51 \%)$ in the United States (33); total economic impact of the crop exceeded $\$ 3$ billion (4). Three regions, including nine additional states, comprise the remainder of the production areas (Fig. 1). They include the Far West (California, Idaho, Oregon, Washington), Great Plains (Colorado, Montana, Nebraska, Wyoming), and Great Lakes (Michigan; Ohio stopped production in 2005), which produced 25, 13 , and $12 \%$ of the total metric tons of roots harvested in 2005, respectively (33). Overall, the annual impact of producing and processing sugar beet in the United States contributes $\$ 4.5$ billion to the economy and over 79,000 full-time equivalent jobs (30).

\section{The Pathogen:}

\section{Aphanomyces cochlioides}

History in sugar beet production. The genus Aphanomyces was erected by deBary in 1860 to include several saprophytic and parasitic aquatic fungi (36). This genus has since been recognized as a

Corresponding author: R. M. Harveson E-mail: rharveso@unlnotes.unl.edu

doi:10.1094/PDIS-91-7-0780

(c) 2007 The American Phytopathological Society sugar beet pathogen for almost 100 years. In 1906, Peters reported the appearance of a severe disease in Germany called "Wurzelbrand" that he attributed to a complex of pathogens, including Aphanomyces laevis, Pythium debaryanum, and Phoma betae (36). In 1915, Edson reported that $A$. laevis was involved with a seedling and root rot complex of sugar beet in the United States (9). He observed that the American pathogen differed morphologically in zoospore formation compared with European isolates (9), and later it was assigned to the genus Pythium (10). Drechsler (8) is credited with naming and describing the current sugar beet root pathogen now known as A. cochlioides Drechs. He isolated the pathogen from diseased seedlings in Michigan, demonstrated pathogenicity, and concluded his $A$. cochlioides was likely the same pathogen that caused "Wurzelbrand" described in Europe by Peters (8).
Distribution and host range. Today $A$. cochlioides is well recognized as a pathogen wherever sugar beet is grown worldwide $(2,31,32,36,38,44)$. In the United States, the pathogen occurs infrequently in the Far West states but is a growing problem in other regions. A. cochlioides was recently identified in Nebraska and Wyoming (12,13), and its known incidence and distribution have been expanding rapidly and now affect production in this region (14). Estimates of sugar beet hectares infested by A. cochlioides in Montana, Colorado, Nebraska, and Wyoming total nearly $35 \%$ and in Michigan are $11 \%$ (B. J. Jacobsen, Montana State University, personal communication). In southern Minnesota, the pathogen infests nearly all sugar beet fields, and in the RRV of Minnesota and North Dakota, it occurs in about $50 \%$ of production fields (5; C. E. Windels, unpublished). American Crystal Sugar Company ( 200,000 ha in the RRV) esti-

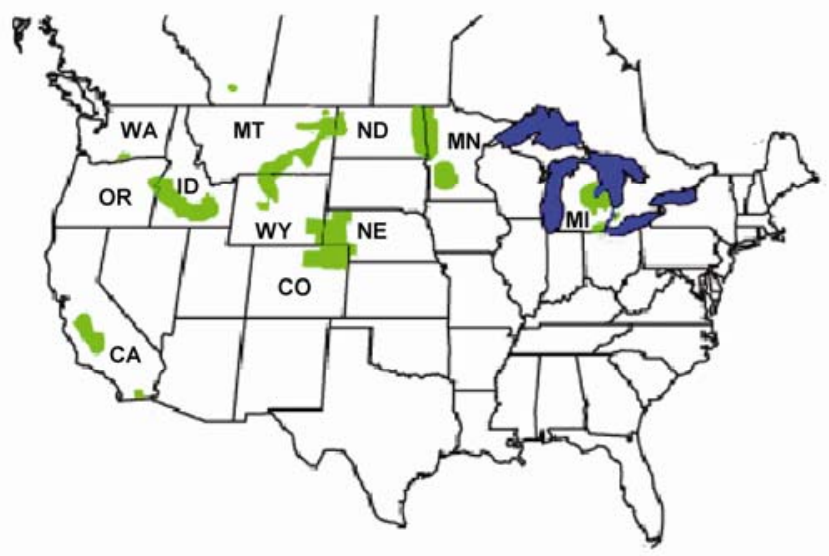

Fig. 1. Sugar beet production regions in the United States are shown in green. Modified from (30), and reprinted with permission of D. Lilleboe, Lilleboe Communications Ltd., Fargo, ND. 
mates that since 1997, Aphanomyces root rot has cost their growers direct losses of $\$ 10$ million annually from abandonment of fields, yield losses from root rot in harvested fields, and storage losses.

A. cochlioides also causes diseases on other commercial crops within B. vulgaris (table beet, mangel, chard), Spinacia oleracea L. (spinach), and several wild species of Beta, including B. maritima L. and B. patellaris Moq. (36). Other field crops are not infected, but some weed species are reported as hosts $(29,36)$.

Symptoms. Root disease caused by $A$. cochlioides can occur as two distinct forms: the acute and chronic phases $(36,41,47,51,52)$. The acute seedling phase is commonly referred to as black root. $A$. cochlioides typically does not cause seed rot or affect initial stand establishment, but can significantly reduce stand by causing damping-off for several weeks after emergence. Symptoms on infected seedlings begin as grayish, water-soaked lesions near soil level that expand rapidly and result in black, shriveled, thread-like hypocotyls and stems (Fig. 2). Cotyledons seldom wilt before seedlings die, which helps distinguish this wilting from wilting associated with seedling disease caused by Rhizoctonia solani and species of Pythium (19).

The chronic root rot phase occurs on plants infected earlier in the season or from new infections on older plants, and is more common in many production areas than the acute phase $(5,14,15,34,41)$. Aboveground symptoms characteristically include stunted plants with foliage that wilts on hot sunny days and recovers at night. Foliage turns a dull green color, eventually turns yellow, and becomes scorched and brittle (Fig. 3). Infections may occur anywhere on taproots, and often appear at junctures of lateral roots and as a characteristic tip rot on the distal end of the root (Fig. 4). Root symptoms begin as yellowish-brown, water-soaked lesions (Fig. 5A) that become darker with age and eventually constrict the root. As rot progresses, the root interior turns yellowish brown from secondary infections. In severe cases, the root tip may disintegrate, leaving only vascular elements (Fig. 6). At harvest, roots affected by chronic root rot typically exhibit scabby lesions and/or malformations of varying intensity (Figs. 5B and 7) that result in yield and sucrose losses $(12,13)$ (Fig. 8). If soil moisture is sufficient, foliage of infected plants may appear healthy, but at harvest, roots easily dislodge from soil $(15,41)$.

Disease cycle. A. cochlioides produces nonseptate hyphae; asexual, short-lived infective zoospores; and sexual, homothallic, over-wintering oospores $(8,36,37,45)$. When soil conditions are favorable for activity (wet and at 15 to $30^{\circ} \mathrm{C}$ ), plants are infected by zoospores or by oospores that germinate and infect plants directly. Zoosporangia (6 to $8 \mu \mathrm{m}$ wide, 400 to 1,000 $\mu \mathrm{m}$ long) are delimited from hyphal branches or germinating oospores to produce primary zoospores that encyst upon emergence from the orifice in a characteristic cluster (Fig. 9A). A secondary biflagellate zoospore emerges from each primary zoospore cyst and swims through soils high in water content. Zoospores are attracted to the root surface by chemical signals released from roots $(22,23,27)$ and then adhere, encyst, germinate, and penetrate the host $(25,26)$.

Eventually, infected tissues cease production of zoospores. Oogonia form and are fertilized by club-shaped antheridia (usually three to four per oogonium). Oo- spores are hyaline to yellow (16 to $24 \mu \mathrm{m}$ in diameter) with granular contents, a large central reserve oil globule ( $12 \mu \mathrm{m}$ diameter), smaller conspicuous refractive body, and are contained within a thick wall (1.5 to $2 \mu \mathrm{m}$ ) (Fig. 9B). Oospores form abundantly in infected plants, but survival appears to be dependent on integrity of host tissue (40).

Disease management. A. cochlioides is intractable once established in fields, and growing sugar beet requires all available options. Some cultural practices are moderately effective and are primarily based on exploiting environmental conditions to reduce or avoid disease development and

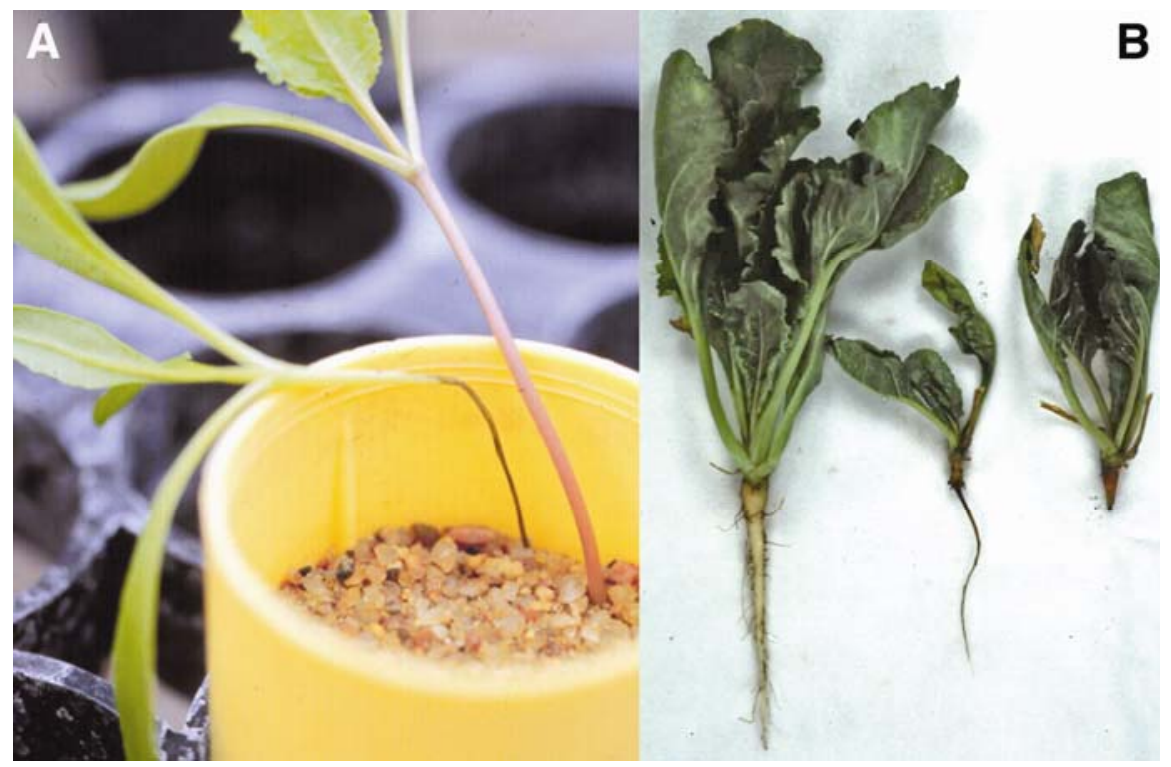

Fig. 2. Aphanomyces seedling disease: A, black, necrotic hypocotyl; B, a healthy seedling (left) compared to advanced symptoms of thin, dark hypocotyl and root (middle), and loss of taproot (right). Note lack of severe wilting of cotyledons.

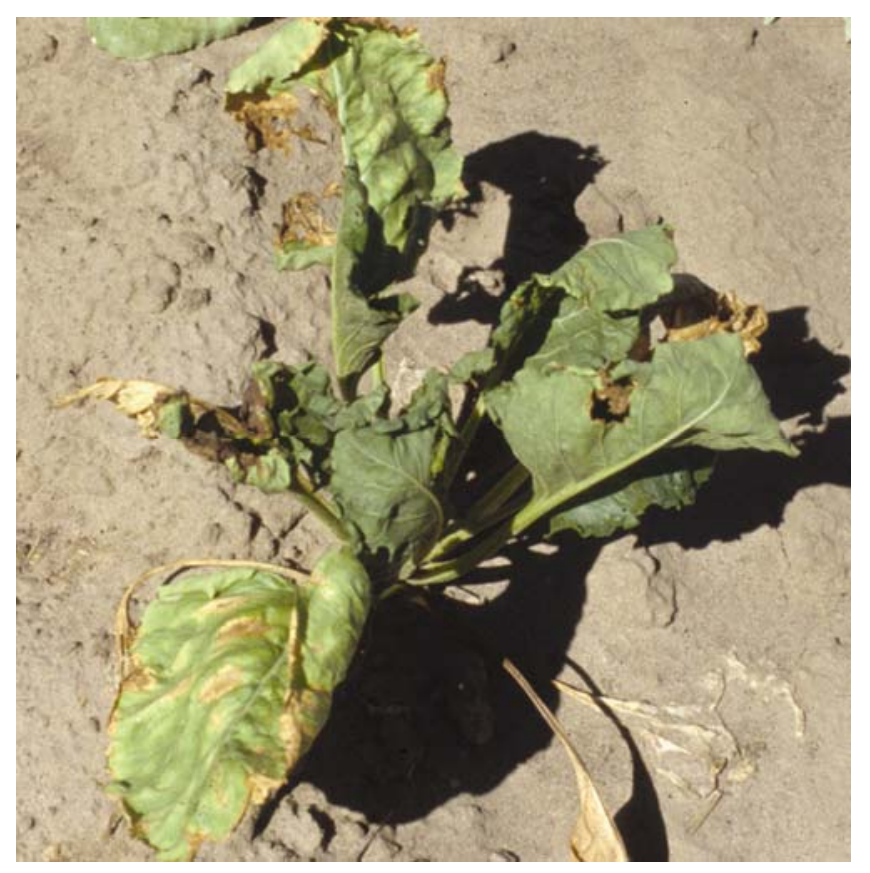

Fig. 3. Aphanomyces chronic root rot: yellowing and scorching symptoms of foliage. 
progression. They include early planting to establish stands before soil temperatures are favorable for infection (42) and reducing irrigation $(18,43)$. Seedling disease from $A$. cochlioides is reduced under irrigation conditions that provide enough soil moisture to enable emergence $\left(<100 \mathrm{~J} \mathrm{~kg}^{-1}\right)$, but not enough to stimulate zoospore production or movement (43). In fields naturally infested with multiple root pathogens, including A. cochlioides, Rhizoctonia solani, Fusarium oxysporum f. sp. betae (and f. sp. betae-radici), Pythium spp., and Beet necrotic yellow vein virus, disease severity was lowered and yield was increased by reducing irrigation frequencies during the season (18). Quantification of irrigation water is difficult, so successful implementation by growers has been erratic and inconsistent. Irrigation rarely is used in
Minnesota, North Dakota, or Michigan where crops are grown under rain fed conditions.

Fumigation of fields has been relatively effective for a complex of pathogens (see list above) including Aphanomyces, but results are inconsistent (16). Fumigation also must be repeated each year a sugar beet crop is grown in severely infested fields, which is economically impracticable. Aphanomyces damping-off can be effectively managed with hymexazol (Tachigaren, Sankyo Agro Co. Ltd., Tokyo, Japan) seed treatment $(17,50)$, but the fungicide has no effect on chronic root rot. To date, no fungicides are available that reduce chronic root rot caused by A. cochlioides.

Genetic resistance is the most efficient and durable method for disease manage-

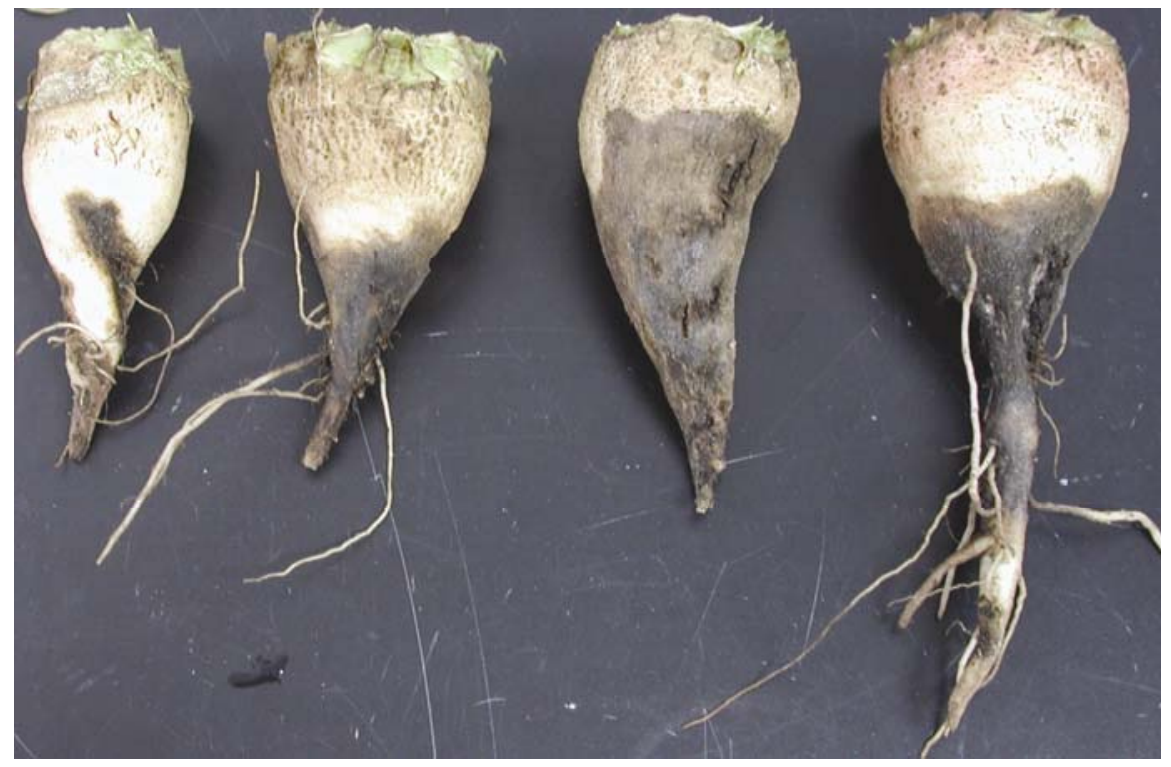

Fig. 4. Aphanomyces chronic root rot: early tip rot symptoms.

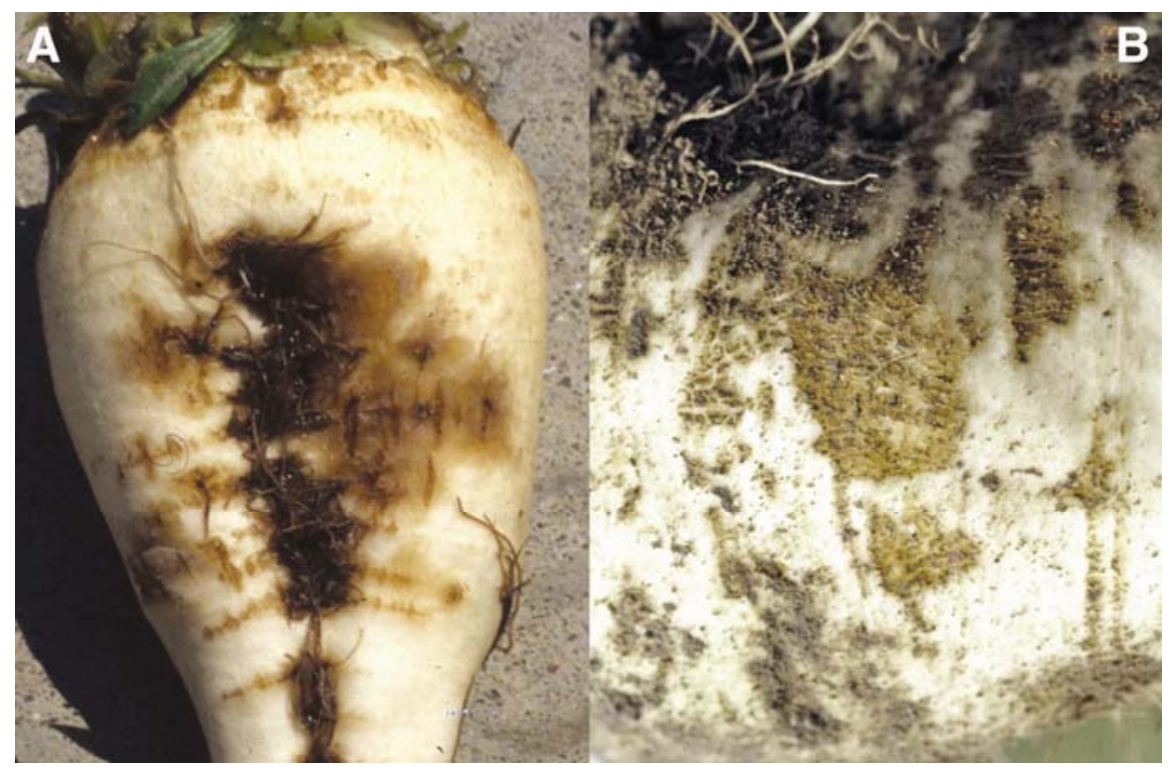

Fig. 5. Aphanomyces chronic root rot: A, early root rot with yellowish-brown, watersoaked lesions, and B, scabby dried lesions after infection has ceased.

ment, but has been difficult to introduce due to multigenic inheritance associated with resistance to $A$. cochlioides (1) and the presence of minor or modifying genes that further increase difficulty in identifying major genes for resistance $(1,20)$. Fortunately, the last few years have seen a tremendous increase in cultivars with good levels of partial resistance for sowing in regions affected by the pathogen. Resistance to $A$. cochlioides is most actively expressed as plants develop (7). Current recommendations are to plant seed of resistant, locally adapted cultivars treated with hymexazol.

\section{Hymexazol: A Novel Source for Disease Management}

The systemic fungicide hymexazol (Tachigaren 70WP, chemical name: 3hydroxy-5-methyl isoamyl-azol) was initiated in the 1960s by Sankyo Co. Ltd. (currently Sankyo Agro Co. Ltd., Tokyo, Japan) as an agent for reducing seedling diseases, improving vigor, and increasing cold resistance in rice. Hymexazol belongs to the heteroaromatic chemical group and affects target organisms by inhibiting RNA synthesis. It exhibits low toxicity potential for mammals and fish, despite being soluble in water. Additionally, it has the unique ability to inhibit species of Aphanomyces and Pythium without affecting other oomycetes including many species of Phytophthora (28). Because of these properties, it is widely used in Phytophthoraselective media to inhibit Pythium in soil dilutions or root isolations. Hymexazol also is the only registered fungicide that controls both Aphanomyces and Pythium,

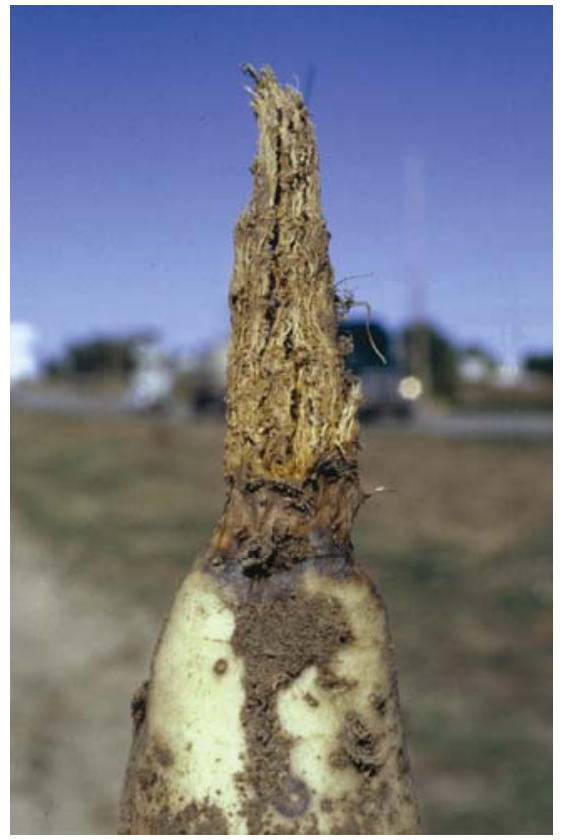

Fig. 6. Aphanomyces chronic root rot: advanced tip rot with disintegration of cortical tissues, leaving tattered remnants of vascular elements intact. 
and thus is used worldwide as a standard treatment for sugar beet seed. The fungicide is active for a few weeks after planting depending upon the rate applied to seed, soil moisture and temperature, and microbial activity. For instance, degradation of hymexazol after 7 days in soil at $15,20,25$, and $30^{\circ} \mathrm{C}$ averages $3.3,7.8,15$, and $24 \%$, respectively, (K. Okada, Sankyo Agro Co., Ltd., personal communication) and continues over time (24).

Hymexazol is marketed as a seed treatment for application on pelleted seed. Pelleted seed is coated with inert materials to improve consistency in size and shape, which facilitates uniformity of planting, and also allows incorporation and layering of pesticides without direct contact with seed. Hymexazol first was sold for application on sugar beet seed in Japan in 1969, followed by Russia in 1975, eastern Europe in the late 1970s, and western Europe in the 1980s (K. Okuno, Summit Agro International Ltd., Tokyo, Japan, personal communication). Since 1984, more than 2 million ha of hymexazoltreated sugar beet seed are sown annually in Europe. Rates of hymexazol differ among countries, depending on disease pressure, but usually are applied at 10 to 21 g a.i. per unit (about 100,000 seed or approximately $1 \mathrm{~kg}$ medium-sized seed) $(21,39)$. In France, growers with severely infested fields can purchase seed treated with 28 or $42 \mathrm{~g}$ a.i. per unit (3), based on efficacy trials conducted by Bouhout et al. (6).

In the United States, sugar beet seed was treated with fenaminosulf (= diazoben; manufactured as Lesan and Dexon by

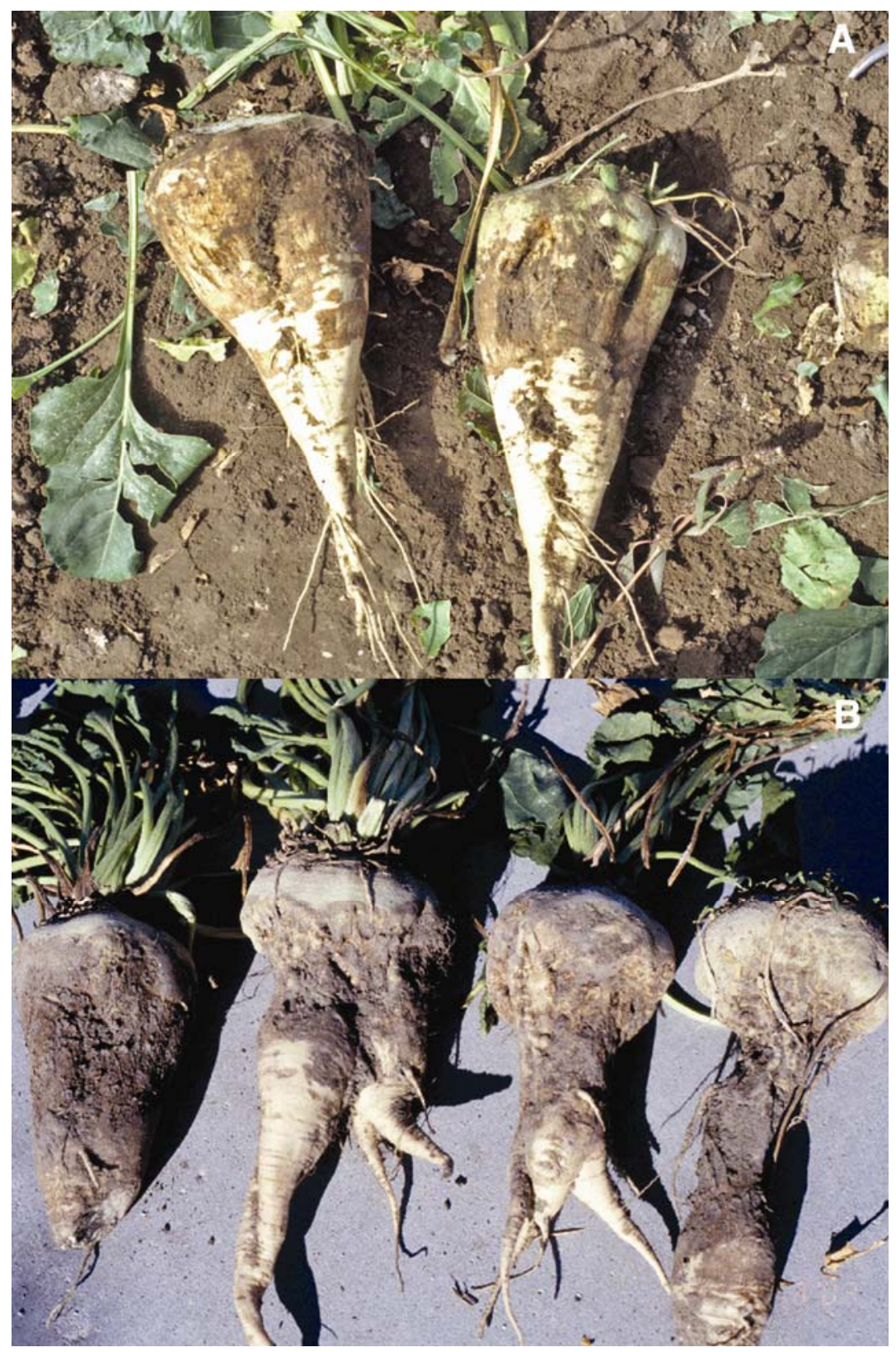

Fig. 7. Aphanomyces chronic root rot: A, mild-moderate scarring, and B, severe root malformation at harvest.
Bayer Corp., Kansas City, MO) for control of $A$. cochlioides and species of Pythium until 1984, when manufacturing of the fungicide was discontinued. Reserves of this inexpensive and effective fungicide continued to be applied to sugar beet seed sown in severely infested fields until supplies were exhausted a couple of years later. Registration of metalaxyl in the United States in 1979 soon replaced fungicides used to control species of Pythium and other oospore-forming pathogens on agricultural, vegetable, horticultural, and other plant species. Unfortunately, metalaxyl has no effect on Aphanomyces, so when shelf-stock reserves of fenaminosulf were gone, no fungicides were available to control this pathogen.

In the 1980s, efforts began to register hymexazol as a sugar beet seed treatment in the United States. With the widespread adoption of the product in Europe, the United States was a relatively large and untapped market. Efforts were initiated in the United States to determine prevalence and disease potential of $A$. cochlioides in sugar beet-growing regions and also to evaluate rates of hymexazol for control of damping-off and early-season root rot.

Soil samples were collected from all sugar beet-growing states and several provinces in Canada. Pathogens were baited from test soils in the greenhouse using sugar beet seedlings. High levels of A. cochlioides were present in production fields in Michigan, Montana, Ohio, Minnesota, and North Dakota (46; C. E. Windels, unpublished). These surveys, in addition to an earlier summary of distribution of $A$. cochlioides in the United States (36), documented the importance of the pathogen.

Controlled environment trials were conducted to evaluate rates of hymexazol already being used in Europe (10.5 to $21 \mathrm{~g}$ a.i./unit) and higher rates (31.5 to $63 \mathrm{~g}$ a.i./unit) in naturally infested soils collected from fields with high Aphanomyces soil index values. Soil index values (SIV) range from 0 to 100 based on a 4-week bioassay in the greenhouse or controlled environment chambers (53). A rating of 0 $=$ no disease, 1 to $39=$ low disease potential, 40 to $69=$ moderate disease pressure, and $\geq 70=$ severe disease potential. In these trials, seed also was treated with standard rates of metalaxyl and thiram (0.3 and $2.1 \mathrm{~g}$ a.i. unit of seed, respectively) to control species of Pythium and Rhizoctonia solani. In growth chamber trials at temperatures favorable for infection, 10.5, 21 , and $31.5 \mathrm{~g}$ a.i. of hymexazol delayed damping-off until about 2 weeks after planting (Fig. 10A), which corresponds to loss of some fungicidal activity. At 21 days after planting, the three rates of hymexazol protected seedlings compared to the control, but the $31.5 \mathrm{~g}$ a.i. rate retained the highest stands (Fig. 10A). Similar trials with 52.5 and $63 \mathrm{~g}$ a.i. rates of hymexazol resulted in very little damping-off by 4 
weeks after planting (Fig. 10B). The $31.5 \mathrm{~g}$ a.i. rate was not as effective as 52.5 or $63 \mathrm{~g}$ a.i. rates of hymexazol, but it delayed disease and reduced stand loss (Fig. 10B) and root rot (Fig. 10C) compared to the control.

Field trials conducted by university researchers (48) and sugar beet companies in numerous studies in the RRV and southern Minnesota showed incremental increases in stand with increases in rates of hymexazol at 4 weeks after planting (Fig. 11). crose yields were not consistently associated with increases in stand because producers typically over-seeded and then thinned fields to desired populations. In Statistically significant increases in su-

field trials with active $A$. cochlioides, however, there was a trend for higher yields of recoverable sucrose in plots from hymexazol-treated seed compared to standard seed treatments (48-50). In field trials in Texas, incidence of seedling disease was significantly reduced when sowing hymexazoltreated seed compared to untreated controls (Table 1). Although hymexazol seed treatment did not protect against chronic root rot, the $31.5 \mathrm{~g}$ a.i. rate resulted in higher tonnage and sucrose yields than when seed was treated with metalaxyl and thiram only (Table 1) (17).

Additional controlled environment experiments showed that all sugar beet culti-

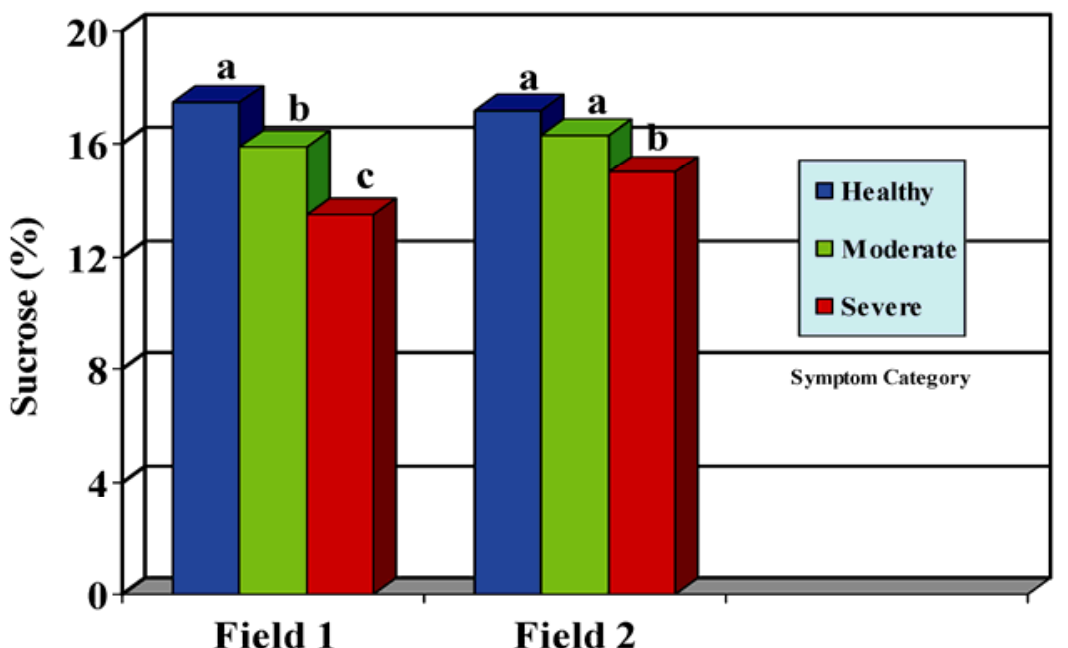

Fig. 8. Sucrose yields from sugar beet roots representing healthy, moderate (defined as mild-moderate scarring, see Figure $7 \mathrm{~A}$ ), and severe rot (defined as severe distortion and malformation, see Figure 7B) (five replicates per category) collected in two fields infested with Aphanomyces cochlioides. For each location, values followed by the same letter are not significantly different, according to Fisher's LSD, $P>0.05$.

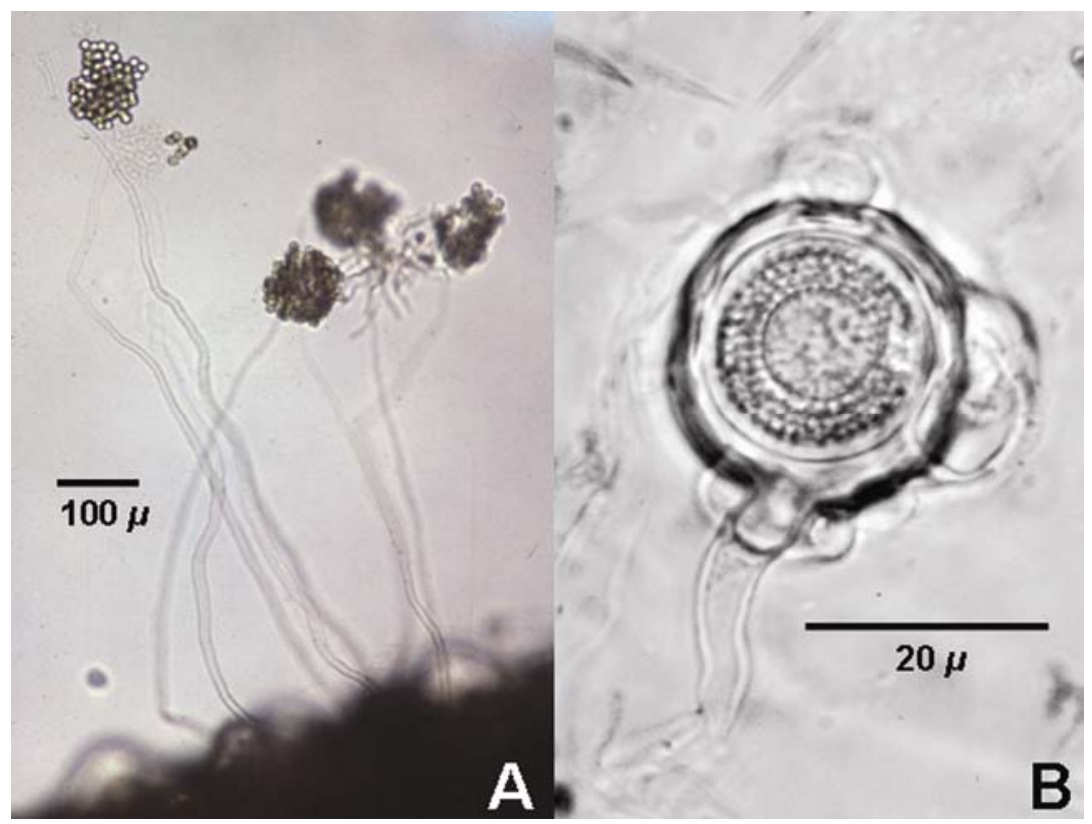

Fig. 9. Spores of Aphanomyces cochlioides. A, asexually produced, secondary zoospores clustering around tips of zoosporangia. B, sexually produced, overwintering oospore. Panel B reprinted by permission. A. T. Dyer and C. E. Windels. 2003. Viability and maturation of $A$. cochlioides oospores. Mycologia 95(2):321-326. vars, regardless of susceptibility to $A$. cochlioides, benefited from seed treatment with hymexazol. Seed of 17 commercial sugar beet cultivars (14 with partial resistance to A. cochlioides, 3 susceptible) treated with $31.5 \mathrm{~g}$ a.i. per unit or with no hymexazol (seed also treated with metalaxyl and thiram) were sown in soil col-
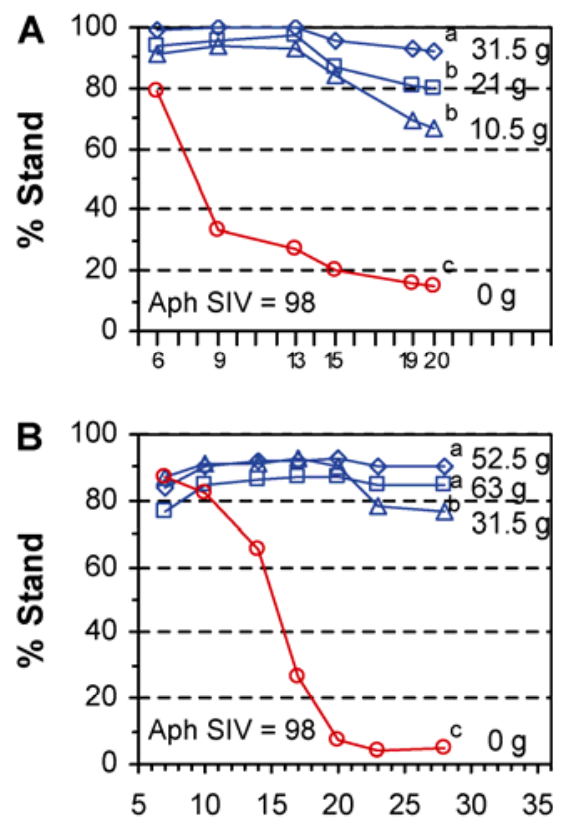

Days after planting

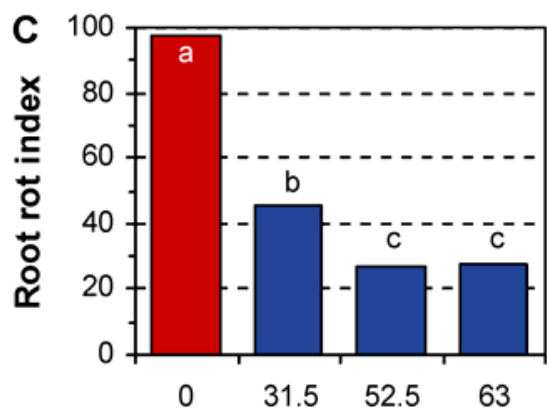

Hymexazol (g a.i./unit)

Fig. 10. Sugar beet was sown in soil collected from fields with high Aphanomyces soil index values (Aph SIV; 0 to 100 scale, $0=$ no disease, $100=$ all seedlings dead in a 4-week assay [53]) based on a 4-week seedling assay. Trials were conducted in controlled environment chambers to favor emergence and activity of Aphanomyces cochlioides (5). Pelleted seed was treated with $0,10.5,21$, or 31.5 g a.i. hymexazol per unit (70WP Tachigaren) and evaluated for $A$, percent stand. Pelleted seed also was treated with 0 , $31.5,52.5$, and $63 \mathrm{~g}$ a.i. hymexazol per unit seed and evaluated for $B$, percent stand, and $C$, root rot 4 weeks after planting. All seed was treated with standard rates of metalaxyl and thiram (0.3 and $2.1 \mathrm{~g}$ a.i. per unit, respectively). For the last stand counts and root rot indices, values followed by the same letter are not significantly different, Fisher's protected least significant difference, $P=$ 0.05 . 
lected from a field with a high Aphanomyces SIV. Stands of partially resistant (Fig. 12A) and susceptible (Fig. 12B) cultivars treated with hymexazol resulted in similar and significantly higher stands compared to the control, where few seedlings survived. Since resistance of sugar beet to $A$. cochlioides starts to be expressed about 3 to 4 weeks after planting (7), hymexazol protects seedlings while they are most vulnerable.

In the meantime, several companies worked together to support registration of hymexazol (Tachigaren 70WP). They included Sankyo Co., the manufacturer; Sumitomo Corp. of America, an overseas trading company that represented Sankyo; Seed Systems Co., Gilroy, CA, a seed pelleting company (currently Germain's Technology Group, Gilroy, CA); and Gustafson LLC, Dallas, TX (currently Bayer CropScience), which managed the work (residues, toxicology, product chemistry, etc.) and filed the petition in the name of Sankyo. When used at the suggested recommended rates, hymexazol was phytotoxic on raw seed, so the request included application only on pelleted seed to allow placement of the product outside the pellet. Seed Systems Co. also was marketing pelleted sugar beet seed in the United States, so supporting registration for hymexazol placed the company in a favorable position to ingress a somewhat recalcitrant market. On 3 September 1992, a meeting was held with scientists from the Environmental Protection Agency (EPA) and Sankyo Co. to review available data on hymexazol before submission for registration (J. C. Rockwell, Rockwell Enterprises, Inc., Albuquerque, NM, personal communication). As a result, an applica-

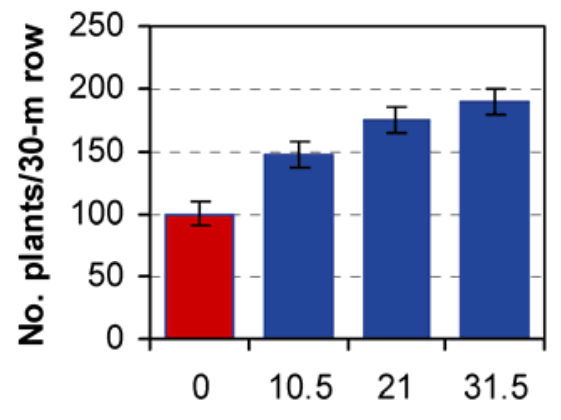

Hymexazol rate

(g a.i./unit seed)

Fig. 11. Average percent stand 4 weeks after sowing pelleted sugar beet seed treated with various rates of hymexazol in 21 fields naturally infested with Aphanomyces cochlioides located in the Red River Valley of Minnesota and North Dakota and in southern Minnesota. All seed was treated with standard rates of metalaxyl and thiram (0.3 and $2.1 \mathrm{~g}$ a.i. per unit seed, respectively). Printed with permission of $\mathrm{K}$. Bigger, Germain's Technology Group, Gilroy, CA (formerly Seed Systems, Inc.). tion for requesting exemption was prepared and submitted on 18 June 1993. It reached the initial EPA screen for completeness on 13 October 1993. Hymexazol was accepted as one of the first "reduced risk" pesticides under new EPA procedures on 11 March 1994.
In the spring of 1994, an Emergency Section 18 exemption request was submitted by Minnesota and North Dakota to the EPA to permit use of hymexazol on pelleted sugar beet seed in 1995. An application also was submitted by Wyoming on 15 July 1994 since the facility where seed was

Table 1. Seedling disease 3 and 4 weeks after planting (WAP) and yield when sowing hymexazol-treated sugar beet in a field near Bushland, TX naturally infested with Aphanomyces cochlioides (17)

\begin{tabular}{|c|c|c|c|c|c|}
\hline \multirow[b]{2}{*}{ Treatment $^{\mathrm{b}}$} & \multicolumn{2}{|c|}{ \% Diseased seedlings ${ }^{\mathrm{a}}$} & \multirow{2}{*}{$\begin{array}{l}\text { Yield } \\
\text { t/ha }\end{array}$} & \multicolumn{2}{|c|}{ Sucrose } \\
\hline & 3 WAP & 4 WAP & & $\%$ & $\mathrm{~kg} / \mathrm{ha}$ \\
\hline Control & 26 & 24 & 37.2 & 16.8 & 5,600 \\
\hline Metalaxyl $(\mathrm{M})+$ thiram $(\mathrm{T})$ & 26 & 26 & 33.4 & 17.2 & 5,000 \\
\hline $\mathrm{M}+\mathrm{T}+31.5 \mathrm{~g}$ hymexazol $(\mathrm{H})$ & 6 & 11 & 40.6 & 17.1 & 6,200 \\
\hline $\mathrm{M}+\mathrm{T}+42 \mathrm{~g} \mathrm{H}$ & 4 & 6 & 37.1 & 17.4 & 5,600 \\
\hline$M+T+63 \mathrm{gH}$ & 3 & 6 & 37.1 & 17.1 & 5,600 \\
\hline $\operatorname{LSD}(P=0.05)$ & 12 & 9 & 5.1 & $\mathrm{NS}^{\mathrm{c}}$ & 800 \\
\hline
\end{tabular}

a Percent seedlings with symptoms typical of $A$. cochlioides.

${ }^{\mathrm{b}}$ Control $=$ untreated seed; metalaxyl + thiram applied at $0.3+2.1 \mathrm{~g}$ a.i. $/ \mathrm{kg}^{-1}$; hymexazol rates in $\mathrm{g}$ a.i. $\mathrm{kg}$ seed $(100,000 \mathrm{seed}=1$ unit $)$.

${ }^{c} \mathrm{NS}=$ not significantly different.
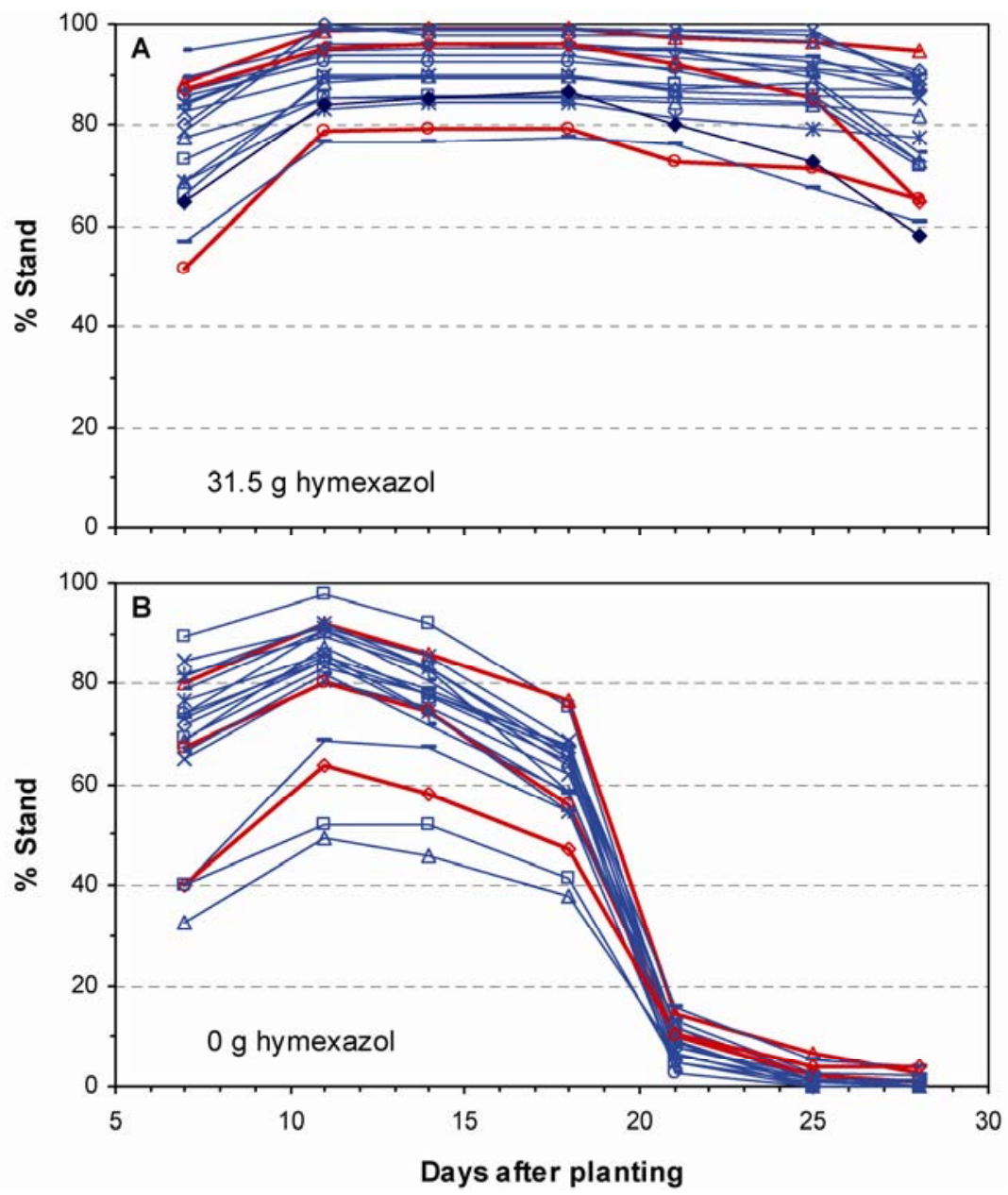

Fig. 12. Average percent stand 28 days after planting seed treated with $31.5 \mathrm{~g}$ a.i. hymexazol per unit compared to no hymexazol (all seed was treated with standard rates of metalaxyl and thiram [0.3 and $2.1 \mathrm{~g}$ a.i. per unit, respectively]) for $A, 14$ cultivars with partial resistance to Aphanomyces cochlioides, and B, three susceptible cultivars. Trials were conducted in environment chambers to favor emergence and activity of Aphanomyces cochlioides (5). For each stand count, values followed by the same letter are not significantly different, Fisher's protected least significant difference, $P=$ $0.05 ; \mathrm{NS}=$ not significant. 
to be pelletized was located there, and EPA defines "use" as where the chemical is applied to seed. During September and October 1994, growers and seed companies sent many letters of support to the EPA requesting a Section 18 exemption. The application was denied on 22 November 1994 on the basis that Aphanomyces diseases are chronic problems of sugar beet and therefore did not pose an emergency, as defined by the Federal Insecticide, Fungicide, and Rodenticide Act (FIFRA).

During this time, application for full registration of hymexazol was being processed and included plant metabolism data by Sankyo Co. Radio-label studies demonstrated that rates of hymexazol requested did not result in detectable residues in mature sugar beet roots. EPA was satisfied with the data and classified the fungicide as a "nonfood" use product-one of only a few chemicals to be assigned this status (J. C. Rockwell, Rockwell Enterprises, Inc., Albuquerque, NM, personal communication). This decision negated the need for extensive and costly residue trials but limited application of hymexazol as a seed treatment. In May 1995, a notice of "Public Interest Funding" was published by EPA in the Federal Register, and on $4 \mathrm{Au}-$ gust 1995, registration was granted for hymexazol (Tachigaren, 70WP) on pelleted sugar beet seed at 31.5 to $63 \mathrm{~g}$ a.i. (45 to $90 \mathrm{~g}$ product/unit).

Sugar beet is one of many crops grown today that depends heavily upon new seed technology. Raw sugar beet seed is irregu-
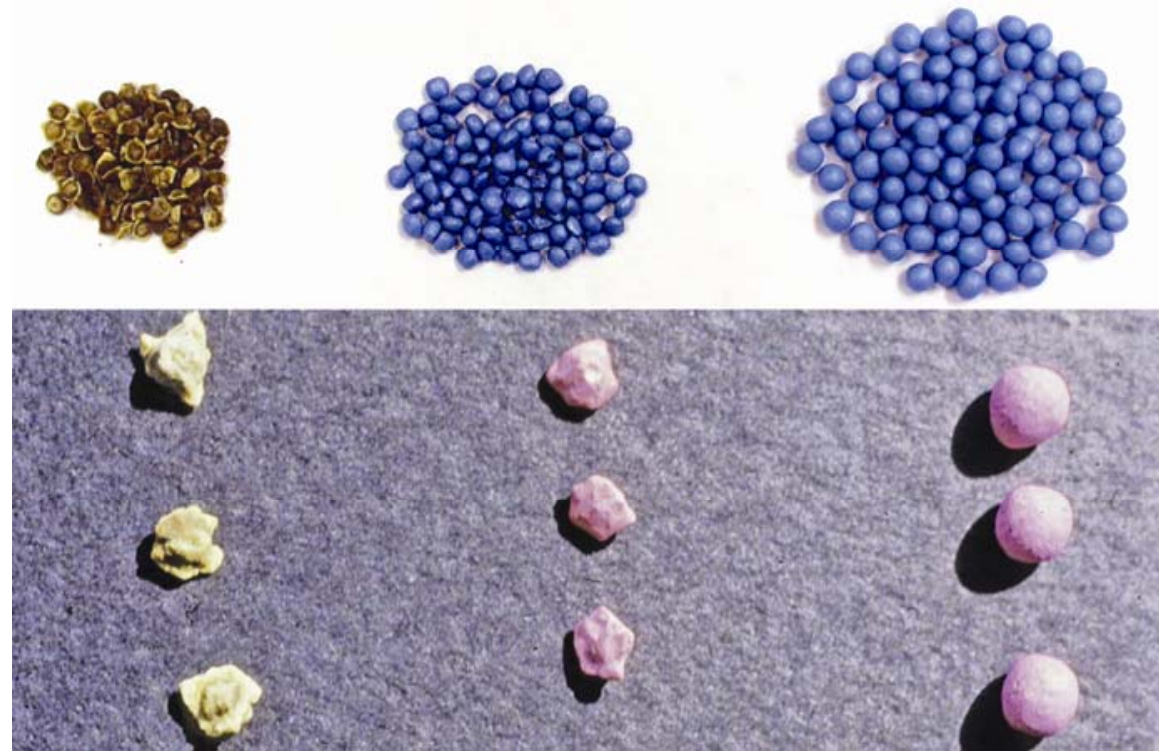

Fig. 13. Sugar beet seeds: raw seed with no coating treatment (left), minimum buildup treatment (center), and full pellet treatment (right).

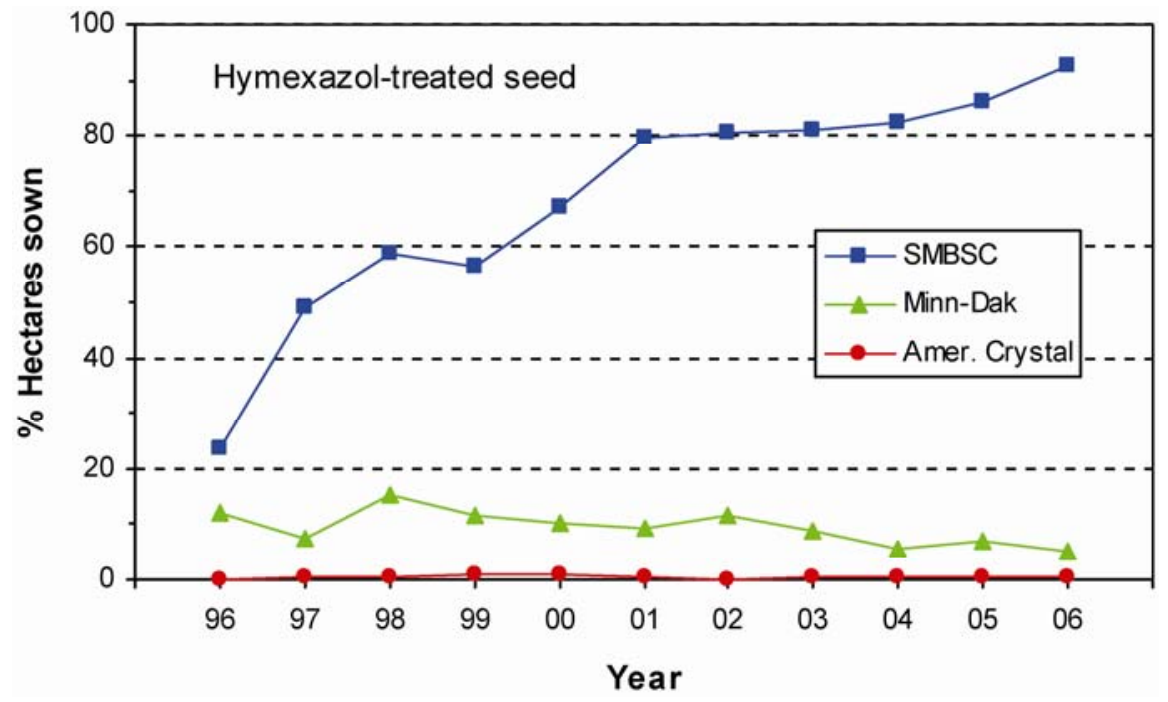

Fig. 14. Percent hectares sown annually with hymexazol-treated sugar beet seed in the Southern Minnesota Beet Sugar Cooperative (SMBSC), Minn-Dak Farmers Cooperative (Minn-Dak), and American Crystal Sugar Company (Amer. Crystal) starting in 1996 when the fungicide first was commercially available in the United States. Data used with permission of each cooperative.

larly shaped (Fig. 13) and varies substantially in size, which affects the precision (spacing, depth, etc.) of planting. Establishment of a good stand was a difficult and inconsistent task before advancements in seed coating technology. Today, many different types of coatings are used in the industry. In general, there are two major types of coating processes: pelleting and some form of minimum buildup (also referred to as encrusting). These processes utilize different names, techniques, and materials that are proprietary for individual companies, but are similar in scope. Pelleting and encrusting results in uniform and round sugar beet seed and thereby improves efficiency and consistency of planting. Secondly, the material used to build coatings can easily be mixed with various pesticides to accurately deliver the desired product into the spermosphere of the germinating seed or applied outside the pellet, as is done with hymexazol.

The full pellet is defined as greater than $200 \%$ buildup, or a minimum weight-toweight ratio of $2: 1$ pelleting mixture to raw seed (Fig. 13). The minimum buildup coating is based on the same concept as the pellet but uses less coating material while still improving uniformity in seeds. Minimum buildup is defined as greater than $30 \%$ buildup with a minimum weight-toweight ratio of $3: 10$ pelleting mixture to raw seed (Fig. 13).

\section{Grower Acceptance of Hymexazol on Pelleted Seed}

Gustafson LLC began marketing hymexazol in the United States and quickly found that unlike in Europe, the product was not widely adopted (K. Rushing, currently with INCOTEC, Salinas, CA, personal communication) because of increased costs associated with seed pelleting and the fungicide. The cost of pelleting a unit of seed was about $\$ 13$ and applying $31.5 \mathrm{~g}$ a.i. of hymexazol was an additional \$15. Thus, a grower who planted hymexazol-treated pelleted seed every $12.7 \mathrm{~cm}$ in rows $0.6 \mathrm{~m}$ apart would use 1.4 units $\mathrm{ha}^{-1}$ at a cost of $\$ 39$ more than sowing nonpelleted seed treated with standard fungicides. In addition, there was reluctance to change planting practices, because sowing pelleted seed required modification or purchase of new equipment. Also, excess purchased seed could not be returned to the seed company (a standard policy) or stored for sowing the following year (hymexazol slowly decomposes on stored seed).

A notable exception occurred in the Southern Minnesota Beet Sugar Cooperative (SMBSC), located in southern Minnesota, where adoption of hymexazol was embraced by producers plagued with a history of fields infested with A. cochlioides and weather favorable for seedling disease. In 1996, $24 \%$ of 43,700 ha sown were treated with the $31.5 \mathrm{~g}$ a.i. rate of 
hymexazol, and by 2006, use had reached $92 \%$ of 47,755 ha (Fig. 14; K. Thompsen, personal communication). In the MinnDak Farmers Cooperative, located in the southern portion of the RRV, producers annually have sown hymexazol-treated seed on 5 to $12 \%$ of total hectares $(47,350$ ha in 2006; T. Knudsen, personal communication). In severely infested fields, sowing an Aphanomyces-resistant cultivar treated with the $31.5 \mathrm{~g}$ a.i. rate of hymexazol has consistently resulted in increases in sucrose yields compared to the same cultivar without hymexazol (M. Metzger, Minn-Dak Farmers Cooperative, personal communication).

Producers in the American Crystal Sugar Company, which includes most of the RRV (200,000 ha), have been reluctant to adopt hymexazol as a seed treatment, and use has averaged $\leq 1 \%$ annually since 1996 (Fig. 14). Although 50\% of sugar beet fields in the RRV are infested with $A$. cochlioides, the acute seedling stage is less common than chronic root rot (5). Spring weather usually is unfavorable for early infection by $A$. cochlioides, but sometimes there are scattered fields with Aphanomyces damping-off. Producers plant as early as possible to lengthen the growing season and avoid warm soil temperatures that favor activity of $A$. cochlioides. Hectares of fields sown with Aphanomyces-resistant cultivars have increased over the years in the American Crystal Sugar Company (Fig. 15) as a result of improved yield and quality, resistance combined with rhizomania resistance, grower education programs, and proven performance in infested fields. Thus, producers have been lulled into cutting production costs by sowing cultivars with partial resistance to A. cochlioides without hymexazol seed treatment, although by doing so, they risk seedling disease in infested fields in wet, warm years.
In Texas, A. cochlioides posed a significant threat to stand establishment $(15,17,41)$, but production ceased in 1997 , thus eliminating an important potential market. Many growers from other geographic locations simply assumed A. cochlioides was absent or occurred at levels too low to justify the added costs of seed treatment in a full pellet ( $\$ 15$ to $\$ 18$ per unit, depending upon local seed companies). Another problem was that hymexazol can occasionally delay germination and emergence and cause phytotoxicity, especially at higher rates and on poor quality seedlots. Finally, infection from A. cochlioides also may have been misdiagnosed and underestimated in some regions such as Nebraska and Wyoming $(13,14)$. All these factors contributed to a general lack of interest in hymexazol outside the Minnesota-North Dakota growing areas.

\section{Fine-Tuning the Marketing Approach}

In 2001, Sankyo Agro Co., Ltd. (formerly Sankyo Co.) and its U.S. distributor Sumitomo Corporation of America applied for an amended label to allow lower dosages of hymexazol (14 and $21 \mathrm{~g}$ a.i. per unit of seed, $70 \% \mathrm{WP}$ ) on minimum buildup pellets. The rationale was to reduce amounts of pelleting material and rates of hymexazol on seed sown in fields with low to moderate disease pressure, a strategy that would reduce costs to $\$ 9$ to $\$ 13$ per unit of hymexazol-treated seed. The lower costs then would be more attractive as an insurance policy to protect against Aphanomyces seedling diseases throughout the United States.

Field trials were conducted in 2001 through 2003 in 14 sites in Michigan, Nebraska, and the RRV of Minnesota and North Dakota to determine if reduced rates of hymexazol on minimum buildup sugar beet seed were phytotoxic and also to

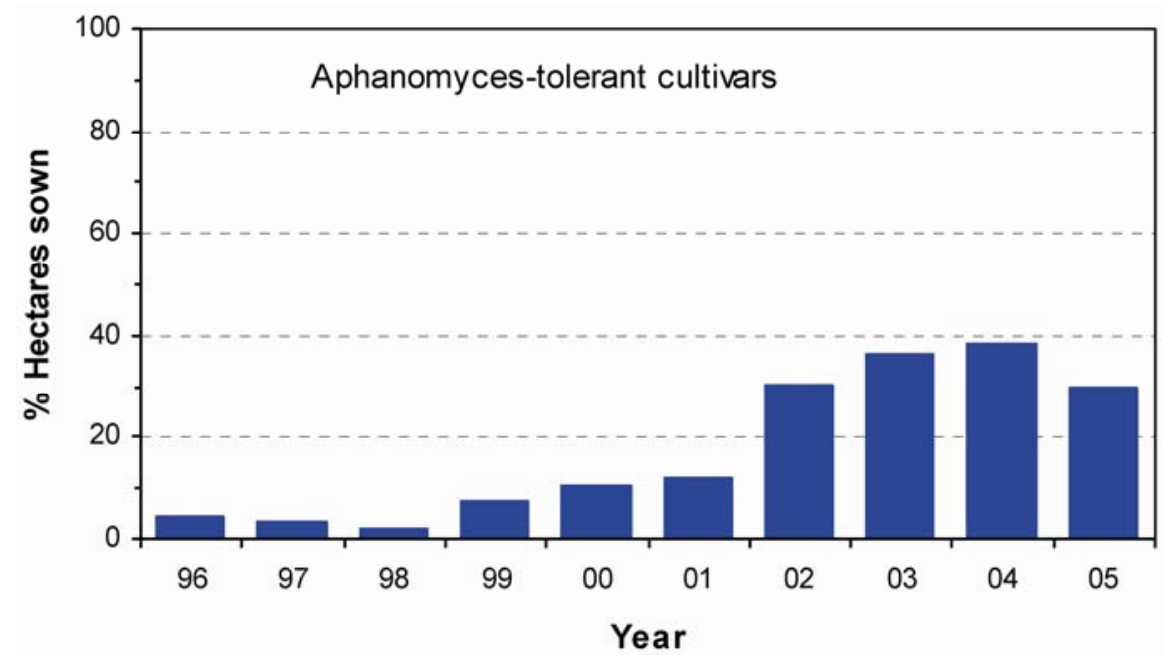

Fig. 15. Percent hectares annually sown with sugar beet cultivars with partial resistance to Aphanomyces cochlioides by the American Crystal Sugar Company (a total of 168,200 ha were sown in 1996 and increased to 206,400 ha by 2006). Data used with permission of American Crystal Sugar Company. measure effectiveness in fields with low levels of infestation with $A$. cochlioides (soil index values $=1$ to 15 ). Hymexazoltreated and control seed were treated with metalaxyl and thiram $(0.3$ and $2.1 \mathrm{~g}$ a.i. per unit) or with thiram ( $2.1 \mathrm{~g}$ a.i. per unit); hymexazol was applied on minimum buildup seed $(14 \mathrm{~g}$ or 14 and $21 \mathrm{~g}$ a.i. per unit) and/or $31.5 \mathrm{~g}$ a.i. on pelleted seed. The disparate geographic regions represented differences in cultivars, planting dates, irrigation methods, climatic conditions, and inoculum levels of A. cochlioides. Sugar beet seed companies provided seed, which was treated by Seed Systems, Gilroy, CA (Michigan and RRV sites) or ASTEC Inc., Sheridan, WY (Nebraska sites) and distributed to university and industry personnel for planting in grower-cooperator fields. In 3 years of trials, the $14 \mathrm{~g}$ a.i rate of hymexazol had no adverse effect on emergence, but at several locations, the $21 \mathrm{~g}$ a.i. rate slightly reduced or delayed emergence (data not shown). Other evidence of phytotoxicity, such as stunted, discolored seedlings, was never observed. Weather was unfavorable for activity of $A$. cochlioides early in the season at 11 of the 14 sites, so benefits of hymexazol seed treatment could not be determined at most sites (data not shown).

The sites where A. cochlioides was somewhat active included two in Minnesota and one in Michigan. At one Minnesota site, plant populations were greater with the $14 \mathrm{~g}$ a.i. rate of hymexazol on minimum buildup seed compared to the standard fungicide control. The other Minnesota site experienced a delay in seedling emergence when seed was treated with hymexazol (14 and $21 \mathrm{~g}$ a.i.) compared to the control, but by 3 weeks after planting, stand was equal for all seed treatments (data not shown). At the Michigan site, the $14 \mathrm{~g}$ a.i. rate of hymexazol resulted in stands similar to the control, but was significantly lower when seed was treated with the $21 \mathrm{~g}$ a.i. rate (data not shown). Overall, $14 \mathrm{~g}$ a.i. per unit of hymexazol on minimum buildup seed proved safe in fields with no activity of $A$. cochlioides, while the $21 \mathrm{~g}$ a.i. rate tended to reduce stands.

Low rates of hymexazol on minimum buildup seed also were evaluated in controlled environment chambers in soils collected from six sites of the 2003 field trials. Negligible Aphanomyces damping-off occurred in these soils, and there were no significant differences in stand with hymexazol on minimum buildup and pelleted seed or the standard control (Fig. 16A). In one of the six soils (from Michigan), there was significantly less root rot and healthier root systems for plants from all hymexazol seed treatments compared to the control at 4 weeks after planting (data not shown).

When soil from three fields with moderate Aphanomyces soil index values (mean $=62$ ) were sown with seed treated with 14 
or $21 \mathrm{~g}$ a.i. hymexazol per unit of minimum buildup seed and the standard con trol, damping-off started about 3 weeks after planting in all soils. One week later, both rates of hymexazol resulted in some stand loss, but plant populations were significantly higher than the control (Fig. 16B) and also had less root rot than the control (data not shown).

\section{Grower Acceptance of Hymexazol on Minimum Buildup Seed}

The label for hymexazol was extended by the EPA in November of 2003 to include the 14 and $21 \mathrm{~g}$ a.i. rates per unit (20 and $30 \mathrm{~g} 70 \mathrm{WP}$ product, respectively) on minimum buildup treated seeds. These rates have been promoted by sugar beet seed companies, the industry, and university personnel for sowing in fields with a history of low levels of Aphanomyces disease. The product can be proactively used in fields where no Aphanomyces diseases have been observed, but are lo-
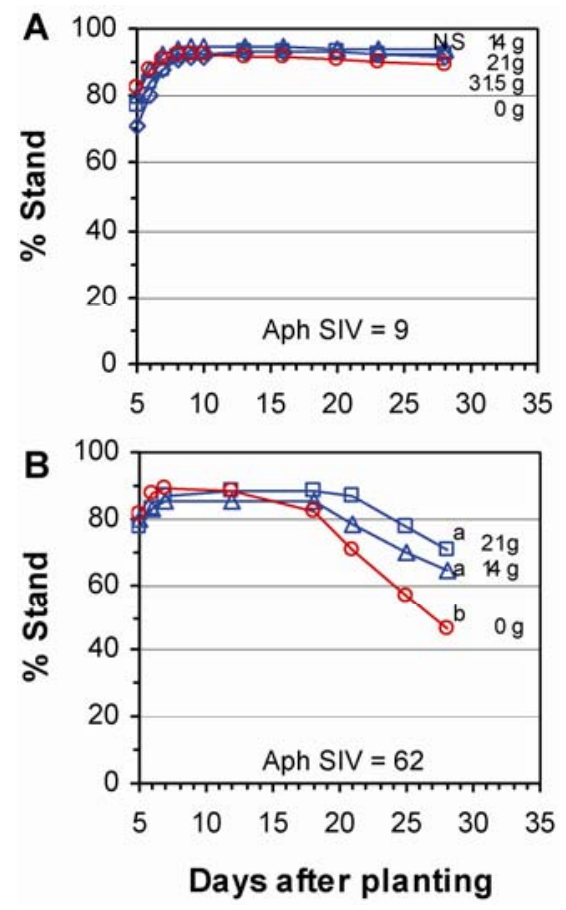

Fig. 16. Average percent sugar beet stand when seed treated with various rates of hymexazol on minimum buildup pellets were sown in $A$, soil from six fields with low Aphanomyces soil index values (Aph SIV; 0 to 100 scale, $0=$ no disease, $100=$ all seedlings dead in a 4week seedling assay [53]), and B, soil from three fields with moderate Aphanomyces SIV. Trials were conducted in environment chambers to favor emergence and activity of Aphanomyces cochlioides (5). All seed was treated with standard rates of metalaxyl and thiram ( 0.3 and $2.1 \mathrm{~g}$ a.i. per unit, respectively). For the last stand count, values followed by the same letter are not significantly different, Fisher's protected least significant difference, $P=0.05$; NS $=$ not significant. cated near fields infested with the pathogen. Currently, commercial sugar beet seed is coated with a minimum buildup material, so the only extra cost is about $\$ 9$ for addition of the $14 \mathrm{~g}$ a.i. rate of hymexazol per unit. In areas with known heavy disease pressure, such as in southern Minnesota and some fields in the RRV, recommendations are to continue using the 31.5 $\mathrm{g}$ a.i. rate of hymexazol on pelleted seed of Aphanomyces-resistant cultivars. For fields with moderate Aphanomyces disease pressure, producers are cautioned that 14 and $21 \mathrm{~g}$ a.i. per unit of seed provide protection, but depending upon duration of favorable weather conditions for infection, are not as reliable as the $31.5 \mathrm{~g}$ a.i. rate.

Since 2003, demand for hymexazol seed treatment has increased in southern Minnesota for the $31.5 \mathrm{~g}$ a.i. rate, but the $14 \mathrm{~g}$ a.i. rate is not used. In the Minn-Dak Farmers Cooperative, the $31.5 \mathrm{~g}$ a.i. rate is applied on seed sown in fields with a history of severe Aphanomyces diseases, and use of the $14 \mathrm{~g}$ a.i. rate is rare (T. Knudsen, personal communication). In the American Crystal Sugar Company, $<1 \%$ of seed sown is treated with hymexazol, and is about evenly split between the $14 \mathrm{~g}$ a.i. rate on minimum buildup seed and the $31.5 \mathrm{~g}$ a.i. rate on pelleted seed.

This is illustrated further by sales from one sugar beet seed company. The percentage of seeds treated with hymexazol in southern Minnesota has increased since 1999 from 51.4 to $89.5 \%$ in 2007 . In the Montana-Wyoming markets, percentages over this same time period have increased from 5.5\% (Sidney, MT) and $0.20 \%$ (Billings, MT/Lovell, WY) in 1999 to 37.3 and $34.2 \%$, respectively, in 2007. Percentages in Colorado-Nebraska markets have remained approximately the same $(12 \%$ in 1999 and $14 \%$ in 2007), while numbers in Worland, WY markets have increased from essentially 0 in 1999 to $70 \%$ in 2007 . Very little hymexazol is used on seed sold in other regions, e.g., Idaho and California (S. Libsack, Betaseed Co., personal communication).

Occasionally, producers have noted the $14 \mathrm{~g}$ a.i. rate of hymexazol on minimum buildup seed slows germination and emergence. These situations, although infrequent, generally are associated with adverse or stressful conditions after planting or with a low-quality seed lot. Thus, users are increasingly cognizant of the balance between potential problems and benefits from sowing sugar beet seed treated with hymexazol.

\section{Overview and Outlook}

This case study illustrates the importance of perseverance, flexibility, and cooperation among numerous agencies and organizations (industry, university, and growers) to register a fungicide for a "minor" crop. Introduction of hymexazol into the U.S. sugar beet industry has had mod- est success, and the fungicide slowly continues to be adopted. Hymexazol is the only fungicide available to control A. cochlioides, so without competition from other products, it has readily been adopted by growers with a history of Aphanomyces seedling disease. These producers also have invested in equipment to sow pelleted seed. Typically, growers resist adopting practices that increase costs of production unless convinced of the benefit, and this has been an evolving challenge. The traditional practice of sowing high seed populations and then thinning to desired stands several weeks later, however, is changing because of increasing costs for seed, handlabor, and mechanical thinning equipment. In recent years, there has been a shift to "planting-to-stand" to reduce seed costs and avoid the extra expense of thinning stands (11). This has improved the popularity of pelleted and minimum buildup (a.k.a. encrusted seed), which also can be metabolically primed $(35,42,43)$ to enhance rate and uniformity of emergence. As a consequence, problems with stand establishment are more apparent compared to over-seeding, and growers are increasingly aware of controlling seedling diseases. Although sugar beet is rotated at least every 3 years, long-term production increases pathogen populations, including A. cochlioides. Once established in a field, this pathogen is intractable and necessitates implementation of effective control measures. Availability of new land for sugar beet production is limited, so disease management practices including seed treatments are expected to become more important. Hymexazol may become a standard seed treatment if $A$. cochlioides continues to spread, but for now, U.S. producers have the option of sowing seed treated with variable rates of hymexazol on pelleted or minimum buildup seed.

\section{Literature Cited}

1. Afanasiev, M. M., and Sharp, E. L. 1961. Testing of inbred lines of sugar beets for resistance to aphanomyces, rhizoctonia, and fusarium root rots. J. Am. Soc. Sugar Beet Technol. 11:542-546.

2. Amein, T. 2006. Soil-borne pathogens infecting sugar beet in southern Sweden. Plant Pathol. J. 5:356-361.

3. Asher, M. J. C., and Payne, P. A. 1989. The control of seed and soil-borne fungi by fungicides in pelleted seed. Pages 179-193 in: Proc. IIRB Congr., Brussels.

4. Bangsund, D. A., and Leistritz, F. L. 2004 Economic contribution of the sugarbeet industry in Minnesota, North Dakota, and Eastern Montana. Agribusiness and Applied Economics Report No. 532, North Dakota State University, Fargo.

5. Beale, J. W., Windels, C. E., and Kinkel, L. L. 2002. Spatial distribution of Aphanomyces cochlioides and root rot in sugar beet fields. Plant Dis. 86:547-551.

6. Bouhout, D., Moncorge, J. M., and RichardMolard, M. 1985. L'Hymexahole, nouveau fongicide contre Pythium spp. et Aphanomyces cochlioides de la betterave sucrière. Maladies des Plantes - A.N.P.P. Journées, 26-27 Févier, 


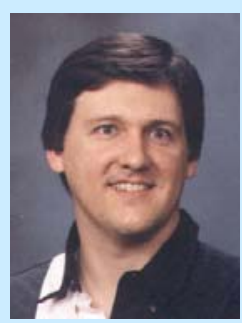

R. M. Harveson

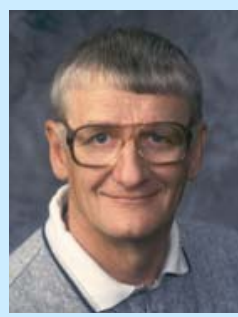

A. W. Cattanach

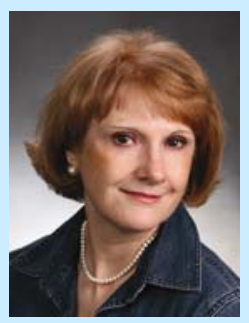

C. E. Windels

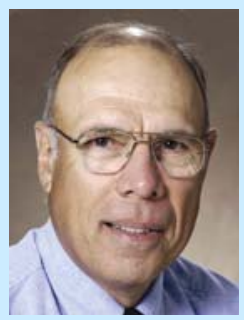

J. F. Giles

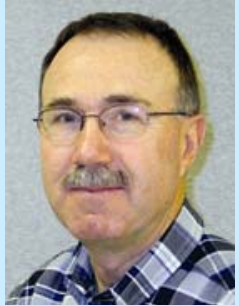

J. A. Smith

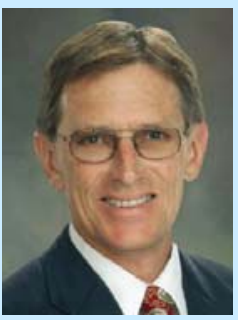

L. Hubbell

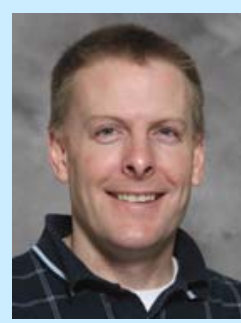

J. R. Brantner

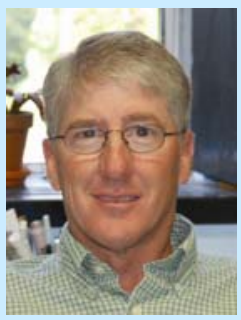

N. R. Cattanach
Dr. Harveson is an associate professor in the Department of Plant Pathology, University of Nebraska. He received his Ph.D. from the University of Florida in 1999 and accepted his current appointment at the Panhandle Research and Extension Center. He received a B.A. in history and a B.S. in plant/soil science from Trinity University and Tarleton State University in 1983 and 1985, respectively. He received an M.S. in plant pathology in 1989 from Texas $A \& M$, then started a new plant disease diagnostic clinic at the Southwestern Florida Research and Education Center in Immokalee. His current appointment involves 50\% research and $50 \%$ extension, with statewide programming responsibility for diseases of specialty crops, including sugar beets and dry-edible beans, potential bio-fuel crops, and other newly emerging alternative crops. His research program focuses on the etiology and management of sugar beet and dry beans diseases using integrated and applied methodologies.

Dr. Windels is a professor at the University of Minnesota, Northwest Research and Outreach Center, Crookston and the Department of Plant Pathology, St. Paul. She has a B.A. in biology from St. Cloud State University, St. Cloud, $\mathrm{MN}$, and M.S. and Ph.D. degrees in plant pathology from the University of Minnesota, St. Paul. Her research program focuses on the etiology and management of sugar beet diseases, with an emphasis on soilborne fungi, particularly Aphanomyces cochlioides and Rhizoctonia solani.

Mr. Smith is a professor in the Biological Systems Engineering Department at the University of Nebraska, and is located at the Panhandle Research and Extension Center in Scottsbluff. He received a B.S. in mechanical engineering from Tri-State College in 1970 and an M.S. in Agricultural Engineering from the University of Wyoming in 1978. $\mathrm{He}$ joined the University of Nebraska in 1981 with a research and extension appointment as a Machinery Systems Engineer. His responsibilities include machinery management for the crops and cropping systems unique to the Nebraska Panhandle. His work has focused on management of field equipment for the tillage, planting, and harvesting of dry-edible beans and sugar beets.

Mr. Brantner is a research fellow in plant pathology for the University of Minnesota and is located at the Northwest Research and Outreach Center, Crookston. He received his B.A. in biology from Concordia College, Moorhead, MN, and M.S. in plant pathology from the University of Minnesota, St. Paul. Since 1995, he has conducted research on the biology and management of soilborne diseases of sugar beet.

Dr. Cattanach has been the general agronomist for American Crystal Sugar Company in Moorhead, MN since 1998. Prior to 1998 , he was the extension sugar beet spe- cialist for North Dakota State University and the University of Minnesota from 1975 to 1998 . He maintains an adjunct professorship in the soil science department. He received his Ph.D. from the University of Minnesota in 1980 in soil science. He obtained a B.S. in soil science from the University of Wisconsin-Madison in 1968 and an M.S. in soil science from North Dakota State University in 1972. His current position involves technical support and training for the 27 agronomists serving company growers, editing the bimonthly sugar beet grower's newsletter, and serving as primary liaison with land grant universities and USDA scientists doing sugar beet research.

Dr. Giles is an emeritus professor in the Department of Soil Science at North Dakota State University. He received his Ph.D. in 1974 from Colorado State University. He obtained a B.S. and M.S. in agronomy from Brigham Young University in 1969 and 1971, respectively. He was hired by South Dakota State University as manager of the James Valley Research and Extension Center located in Redfield, SD, where he served from 1975 to 1979 . Prior to his retirement in 2005, his NDSU appointment involved $15 \%$ teaching and $85 \%$ research. His research program focused on soil and crop residue management and stand establishment of sugar beet using integrated and applied methodologies.

Mr. Hubbell is a research agronomist with Michigan Sugar Company in Bay City. He obtained B.S. and M.S. degrees in agricultural education from Michigan State University in 1974 and 1978, respectively. He earned a B.S. degree in business management from Northwood University in 1995. He began his career with Monitor Sugar Company (now Michigan Sugar Company) in 1985 as a fieldman and then became research manager in 1988. He started his current position as research agronomist in 2005 . He supervises the research program and reports results to the growers. Research includes seed variety trials, pesticide trials, and other cultural practices to benefit sugar beet production.

Mr. Cattanach is a research associate in the Soil Science Department at North Dakota State University. He has served in that position since June 1982 when he began employment as a research assistant. He received his B.S. degree from the University of Wisconsin-River Falls in plant sciences in the spring of 1982 . He provides support to a Ph.D. soil scientist responsible for tillage and soil management research. He has worked with numerous crops including corn, soybeans, dry edible beans, wheat, sugar beet, sunflower, and potato. Tillage research has involved seedbed preparation, stand establishment, planter operation and maintenance, nutrient management, soil erosion, cover cropping systems, and no-till and strip tillage studies. 
1985.

7. Brantner, J. R., and Windels, C. E. 2004. Sugar beet seedling age and susceptibility to Aphanomyces cochlioides. (Abstr.) Phytopathology 94:S10.

8. Drechsler, C. 1929. The beet water mold and several related root parasites. J. Agric. Res. 38:309-361.

9. Edson, H. A. 1915. Seedling diseases of sugar beet and their relation to root-rot and crownrot. J. Agric. Res. 4:135-168.

10. Fitzpatrick, H. M. 1923. Generic concepts in the Pythiaceae and Blastocladiaceae. Mycologia 15:166-173.

11. Fornstrom, K. J. 1980. Planting sugarbeets to stand in Wyoming. J. Am. Soc. Sugar Beet Technol. 20:535-543.

12. Harveson, R. M. 2000. Aphanomyces root rot of sugar beet. NebGuide G00-1407-A. University of Nebraska, Coop. Ext.

13. Harveson, R. M. 2000. First report of Aphanomyces root rot of sugar beet in Nebraska and Wyoming. Plant Dis. 84:596.

14. Harveson, R. M., Hein, G. L., Smith, J. A., Wilson, R. G., and Yonts, C. D. 2002. An integrated approach to cultivar evaluation and selection for improving sugar beet profitability: A successful case study for the Central High Plains. Plant Dis. 86:192-204.

15. Harveson, R. M., and Rush, C. M. 1993. An environmentally controlled experiment to monitor the effect of Aphanomyces root rot and rhizomania of sugar beet. Phytopathology 83:1220-1223.

16. Harveson, R. M., and Rush, C. M. 1994. Evaluation of fumigation and rhizomaniatolerant cultivars for control of a root disease complex of sugar beets. Plant Dis. 78:11971202.

17. Harveson, R. M., Rush, C. M., and Vaughn, K. M. 1994. Seed treatment with Tachigaren for controlling black root of sugar beet. Fungic. Nematicide Tests 49:277. American Phytopathological Society, St. Paul, MN.

18. Harveson, R. M., and Rush, C. M. 2002. The influence of irrigation management and cultivar blends on the severity of multiple root diseases in sugar beets. Plant Dis. 86:901-908.

19. Harveson, R. M. 2006. Identifying and distinguishing seedling and root rot diseases of sugar beets. Online. Plant Health Progress doi:10.1094/PHP-2006-0915-01-DG.

20. Hecker, R. J., and Ruppel, E. G. 1975. Inheritance of resistance to Rhizoctonia root rot in sugarbeet. Crop Sci. 15:487-490.

21. Heijbroek, W., and Huijbregts, A. W. M. 1995. Fungicides and insecticides applied to pelleted sugar-beet seeds - II. Control of pathogenic fungi in soil. Crop Prot. 14:363-366.

22. Horio, T., Kawabata, Y., Takayama, T., Tahara, S., Kawabata, J., Fukushi, Y., Nishimura, H., and Mizutani, J. 1992. A potent attractant of zoospores of Aphanomyces cochlioides isolated from its host, Spinacea oleracea. Experi- entia 48:410-414

23. Horio, T., Yoshida, K., Kikuchi, H., Kawabata, J., and Muzutani, J. 1993. A phenolic amide from roots of Chenopodium album. Phytochemistry 33:807-808.

24. Huijbregts, A. W. M., Gijssel, P. D., and Heijbroek, W. 1995. Fungicides and insecticides applied to pelleted sugar-beet seeds - I. Dose, distribution, stability and release patterns of active ingredients. Crop Prot. 14:355-362.

25. Islam, M. T., Ito, T., and Tahara, S. 2001. Morphological studies on zoospores of Aphanomyces cochlioides and changes during interaction with host materials. J. Gen. Plant Pathol. 67:255-261.

26. Islam, M. T., Ito, T., and Tahara, S. 2002. Microscopic studies on attachment and differentiation of zoospores of the phytopathogenic fungus Aphanomyces cochlioides. J. Gen. Plant Pathol. 68:111-117.

27. Islam, M. T., and Tahara, S. 2001. Chemotaxis of fungal zoospores, with special reference to Aphanomyces cochlioides. Biosci. Biotechnol. Biochem. 65:1933-1948.

28. Kato, S., Coe, R., New, L., and Dick, M. W. 1990. Sensitivities of various Oomycetes to hymexazol and metalaxyl. J. Gen. Microbiol. 136:2127-2134.

29. Larsson, M. 1994. Pathogenicity, morphology, and isozyme variability among isolates of Aphanomyces spp. from weeds and various crop plants. Mycol. Res. 98:231-240.

30. Lilleboe, D. 2006. 2005/06 U.S. Sugar Industry Directory. Lilliboe Communications Ltd., Fargo, ND.

31. Martin, H. L. 2003. Management of soilborne diseases of beetroot in Australia: A review. Aust. J. Exp. Agric. 43:1281-1292.

32. McKeen, W. E. 1949. A study of sugar beet root rot in southern Ontario. Can. J. Res. 27:284-311.

33. National Agriculture Statistics Service. 2007. U.S. Dep. Agric. Nat. Agric. Stat. Serv. Online.

34. Olsson, A., and Olsson, R. 2004. Geographic distribution of the soilborne fungus Aphanomyces cochlioides in Sweden. Page 69 in: Proc. IIRB Congr., 67th.

35. Osburn, R. M., and Schroth, M. N. 1989. Effect of osmopriming sugar beet seed on germination rate and incidence of Pythium $u l$ timum damping-off. Plant Dis. 73:21-24.

36. Papavizas, G. C., and Ayers, W. A. 1974. Aphanomyces species and their root diseases in pea and sugarbeet. U.S. Dep. Agric. Tech. Bull. 1485.

37. Parke, J. L., and Grau, C. R. 1992. Aphanomyces. Pages 27-30 in: Methods for Research on Soilborne Phytopathogenic Fungi. L. L. Singleton, J. D. Mihail, and C. M. Rush, eds. American Phytopathological Society, St. Paul, $\mathrm{MN}$.

38. Payne, P. A., Asher, M. J. C., and Kershaw, C. D. 1994. The incidence of Pythium spp. and Aphanomyces cochlioides associated with the sugar-beet growing soils of Britain. Plant Pathol. 43:300-308

39. Payne, P. A., and Williams, G. E. 1990. Hymexazol treatment of sugar-beet seed to control seedling disease caused by Pythium spp. and Aphanomyces cochlioides. Crop Prot. 9:371-377.

40. Rowntree, J., and Windels, C. E. 2004. Survival of Aphanomyces cochlioides oospores in soil following preconditioning at different relative humidities. (Abstr.) Phytopathology 94:S90.

41. Rush, C. M. 1990. Seedling and root rot diseases of sugar beet in Texas. Texas Agricultural Experiment Station, AREC-CTR 90-4.

42. Rush, C. M. 1992. Stand establishment of sugar beet seedlings in pathogen-infested soils as influenced by cultivar and seed-priming techniques. Plant Dis. 76:800-805.

43. Rush, C. M., and Vaughn, K. M. 1993. Effect of irrigation, soil matric potential, and seed priming on sugar beet germination and damping-off caused by Aphanomyces cochlioides. Phytopathology 83:202-206.

44. Schneider, C. L., and Whitney, E. D. 1986 Black root. Page 17 in: Compendium of Beet Diseases and Insects. E. D. Whitney and J. E. Duffus, eds. American Phytopathological Society, St. Paul, MN.

45. Scott, W. W. 1961. A Monograph of the Genus Aphanomyces. Va. Agric. Exp. Stn. Tech. Bull. 151.

46. Vaughn, K. M., and Rush, C. M. 1995. A survey of Aphanomyces cochlioides from sugar beet production areas in the United States and Canada. (Abstr.) J. Sugar Beet Res. 32:162.

47. Windels, C. E. 2000. Aphanomyces root rot of sugar beet. Online. Plant Health Progress:10.1094/PHP-2000-0720-01-DG.

48. Windels, C. E., Bredehoeft, M., and Watkins, R. 1997. Performance of Tachigaren as a sugarbeet seed treatment in 1996 field trials. 1996 Sugarbeet Res. Ext. Rep. 27:244-251.

49. Windels, C. E., Brantner, J. R., Cattanach, A. W., and Lamey, H. A. 1999. Evaluation of sugarbeet varieties with partial resistance/tolerance to Aphanomyces. 1998 Sugarbeet Res. Ext. Rep. 29:257-269.

50. Windels, C. E., Cattanach, A. W., and Lamey, H. A. 1988. Field evaluation for control of Aphanomyces by Tachigaren ${ }^{\circledR}$ seed treatment. 1987 Sugarbeet Res. Ext. Rep. 18:139-143.

51. Windels, C. E., and Jones, R. K. 1989. Seedling and root rot diseases of sugarbeets. University of Minnesota, AG-FO-3702.

52. Windels, C. E., and Lamey, H. A. 1998. Identification and control of seedling diseases, root rot, and rhizomania on sugarbeet. North Dakota State Univ., Ext. Serv./Univ. Minnesota Ext. Serv. PP-1142 BU-7192-S.

53. Windels, C. E., and Nabben-Schindler, D. J. 1996. Limitations of a greenhouse assay for determining potential of Aphanomyces root rot in sugarbeet fields. J. Sugar Beet Res. 33:1-13. 